DOI: https://doi.org/10.35387/ucj.1(3).2021.66-73

АНАСТАСІЯ ПОПОВА

\title{
ОСНОВНІ ЗАСАДИ ОРГАНІЗАЦІЇ ПРОФЕСІЙНОГО РОЗВИТКУ СОЦІАЛЬНИХ ПРАЦІВНИКІВ У ПРОВІНЦІЇ КАНАДИ АЛЬБЕРТА
}

\begin{abstract}
Анотація. У статті розкрито основні засади організації професійного розвитку соціальних працівників у провінції Канади Альберта. З'ясовано, що безперервний професійний розвиток соціальних працівників в провінції Канади Альберта - це важливий елемент функціонування якісної професійної практики у цій галузі, який забезпечує нерозривний зв'язок сучасної науки і професійної діяльності і реалізується шляхом участі у програмі безперервної компетентності. Встановлено, що необхідність і обов'язковість професійного розвитку соціальних працівників у провінції Альберта визначено Законом про медичні професії, Положенням про професії соціальних працівників, а також Кодексом етики та Стандартами практики соціальної роботи. Визначено, що відповідальність за професійний розвиток покладено на Альбертійський коледж соціальних працівників у межах повноважень якого реалізуються регуляторна, організаційно-практична, контролююча, адвокаційна функції. Схарактеризовано компоненти (самооцінка, навчальний план, форма кредитів професійного розвитку, портфоліо) програми безперервної компетентності. Доведено, що системний підхід до організації безперервного професійного розвитку соціальних працівників у провінції Альберта забезпечує можливість реалізації права кожного громадянина Канади на якісне соціальне обслуговування, дотримання етичних і професійних стандартів, заохочення інноваційних й ефективних стратегій і методів професійної діяльності для задоволення як нових, так і існуючих потреб клієнтів, досягнення високого рівня соціальної справедливості і соціального розвитку та актуалізує вивчення, аналіз та узагальнення альбертійського досвіду задля впровадження конструктивних ідей в украӥнську практику.
\end{abstract}

Ключові слова: професійний розвиток, соціальний працівник, соціальна робота, програма безперервної компетентності, Канада, провінція Альберта.

\section{BASIC PRINCIPLES OF ORGANIZATION SOCIAL WORKERS' PROFESSIONAL DEVELOPMENT IN THE PROVINCE ALBERTA CANADA}

\begin{abstract}
The article reveals the basic principles of the organization social workers' professional development in the province of Alberta Canada. The social workers' continuing professional development in Alberta Canada, has been found to be an important element of the professional practice quality in this field, which ensures the inextricable link between modern science and professional activity and is realized through participation in the continuing competence program. It is established that the necessity and obligatory of social workers' professional development in the province of Alberta is determined by the Health Professions Act, Social Workers Profession Regulation, as well as the Code of Ethics and Standards of Practice. It is determined that the responsibility for professional development is assigned to the Alberta College of Social Workers, within the powers of which the regulatory, organizational-practical, controlling, and advocacy functions are exercised. The components of the continuous competence program such as self-assessment, learning plan, professional development credits form, portfolio are characterized. It has been proven that a systematic approach to the social workers' continuing professional development in Alberta enables the realization of every Canadian citizen's right to quality social services, ethical and professional standards, and the promotion of innovative and effective professional strategies and methods to meet both new and existing customer needs, achieving a high level of social justice and social development and updating the study, analysis and generalization of the Alberta experience in order to implement constructive ideas in Ukrainian practice.

Key words: professional development, social worker, social work, continuing competence program, Canada, Alberta.
\end{abstract}

Вступ. У сучасних умовах динамічних змін, що відбуваються в усіх сферах суспільного життя України - соціальна робота $€$ стратегічним ресурсом соціального розвитку і детермінантою соціального благополуччя громадян нашої країни. Важливою складовою ефективної соціальної роботи є якісна підготовка соціальних працівників та розробка ефективних моделей безперервного навчання, які б забезпечували можливість безперервного професійного розвитку фахівців із соціальної роботи. 
Україна знаходиться на шляху реформування системи соціальної політики і соціальної роботи у відповідності до міжнародних і національних стандартів. Тому, актуальними проблемами, які потребують вирішення є створення професійних стандартів діяльності у галузі соціальної роботи, формування мережі професійних і освітніх організацій у галузі соціальної роботи, розробка комплексної системи професійного розвитку соціальних працівників, яка була б побудована на засадах наступності та 3 урахуванням випереджувального й прогностичного підходів. У контексті зазначеного, досвід діяльності професійних організацій у галузі соціальної роботи та системи професійного розвитку у Канаді, зокрема у її провінції Альберта відкриває нові можливості для удосконалення практики соціальної роботи і професійного розвитку соціальних працівників в Україні в умовах іiї адаптації до вимог міжнародного освітнього простору.

Мета дослідження. Спираючись на доцільність вивчення та систематизації зарубіжного досвіду у контексті професійного розвитку соціальних працівників нами визначена мета статті - теоретично обгрунтувати основні засади організації системи професійного розвитку соціальних працівників у провінції Канади Альберта та виявити можливості творчого використання конструктивних ідей досвіду провінції Канади Альберта в Україні.

Теоретичні основи та методи дослідження. За роки незалежності України та періоду становлення вітчизняної практики соціальної роботи та системи підготовки соціальних працівників посилився інтерес дослідників-компаративістів до вивчення системи підготовки і професійного розвитку соціальних працівників у розвинених країнах світу. Теорію і практику професійної підготовки соціальних працівників у зарубіжних країнах вивчали Н. Гайдук, Л. Клос, Н. Собчак, В. Тименко, О. Ольхович (США і Канада), Н. Видишко, Н. Микитенко, С. Ставкова (Канада), I. Ковчина (Польща), O. Пічкар, І. Різак (Велика Британія), Г. Лещук (Франція). Різні аспекти підготовки і професійного розвитку соціальних працівників у Канаді представлені у наукових розвідках Н. Видишко, Н. Гайдук, Н. Микитенко. Загальний опис та структура освіти до- рослих Канади проаналізована у дослідженнях Н. Теренко.

Важливими для нашого дослідження стали: наукові доробки таких зарубіжних вчених, а саме 0. Наттман-Шварца (O.Nuttman-Shwartz), Дж. C. C. Чунга (J. C. S. Cheung), зокрема канадських К. Макколі (К. McCauley), Д. Метісона (D. Matheson), які у своїх працях розкрили основні основні засади та роль професійного розвитку соціальних працівників у Канаді; а також інтернет-ресурси офіційних сайтів Міжнародної асоціації шкіл соціальної роботи (The International Association of Schools of Social Work (IASSW), Міжнародної федерації соціальних працівників (International Federation of Social Workers), Канадської асоціації у сфері соціальної роботи (Canadian Association of Social Workers (CASE), Альбертійського коледжу соціальних працівників (Alberta College of Social Workers (ACSW).

Водночас, незважаючи на результати цих та інших міждисциплінарних наукових пошуків, дослідження професійного розвитку соціальних працівників у провінціях Канади, зокрема у провінції Альберта не було предметом системного вивчення, що актуалізує необхідність висвітлення цієї наукової проблеми в рамках визначеної мети дослідження.

Для досягнення мети використано комплекс взаємодоповнюючих методів: загальнонаукові (аналіз, синтез, систематизація, узагальнення - використовувалися для вивчення праць зарубіжних і вітчизняних науковців, інформації з офіційного сайту Альбертійського коледжу соціальних працівників ); конкретно-наукові: (категоріальний аналіз - для розкриття змісту й уточнення дефініцій основоположних понять; структурно-функціональний аналіз - для з'ясування структурних, змістових і процесуальних особливостей діяльності Альбертійського коледжу соціальних працівників та організації програми безперервної компетентності; контент-аналіз - для вивчення офіційних інструкцій, планів і форм програми безперервної компетентності); прогностичні - для виявлення можливостей творчого використання конструктивних ідей досвіду провінції Канади Альберта в Україні. 
Виклад основного матеріалу. Освіта у сфері соціальної роботи не є статичним, одноразовим досвідом навчання на бакалаврських і магістерських освітніх програмах. Оскільки соціальний ландшафт постійно змінюється, практикуючим соціальним працівникам надзвичайно важливо оволодівати сучасними знаннями, ідеями та передовим досвідом у своїх сферах практики, що зумовлює необхідність здійснення безперервного професійного розвитку, який $є$ обов'язковим елементом професійної практики соціальних працівників у розвинених країнах світу (Nuttman-Shwartz, 2018).

Реєстраційна рада соціальних працівників Ірландської мультипрофесійної організації у сфері охорони здоров'я та соціального добробуту (Ireland's multi-profession health regulator (CORU), 2021) розглядає безперервний професійний розвиток Continuing Professional Development (CPD) як один із ключових механізмів для підтримки високих стандартів професійної діяльності та професійної освіти, навчання та компетентності серед зареєстрованих соціальних працівників.

Англійська асоціація місцевого самоврядування (Local Government Association in England, 2021), яка здійснює регулювання професійної діяльності у галузі соціальної роботи стверджує у своїх статутних документах, що безперервний професійний розвиток - це рефлексія та навчальна діяльність, яку соціальні працівники здійснюють протягом своєї кар'єри, щоб підтримувати та покращувати свою практику. Це важлива частина стандартів професійної діяльності соціального працівника. Організація та фіксація безперервного професійного розвитку дозволяє соціальному працівнику демонструвати громадськості, координуючому та реєстраційному органу та роботодавцю, що він дотримуються цих професійних стандартів.

Канадська асоціація у сфері соціальної роботи (Canadian Association of Social Workers (CASE), 2021) розглядає професійний розвиток як системну діяльність соціального працівника із підвищення своєї компетентності, що включає низку формувальних практик, таких як самоаналіз, навчання та атестацію на засадах етики і стандартів практики соціальної роботи.
Виходячи із трактувань поняття «безперервний професійний розвиток» та їх офіційних джерел керування цим процесом $€$ одним із найважливіших завдань професійних асоціацій та державних регулюючих органів у сфері соціальної роботи. На міжнародному рівні регуляторну політику стосовно стандартів практики і неперервної професійної підготовки соціальних працівників здійснюють Міжнародна асоціація шкіл соціальної роботи (The International Association of Schools of Social Work (IASSW) та Міжнародна федерація соціальних працівників (International Federation of Social Workers). Обидві організації мають консультативний статус при ООН і здійснюють свою діяльність у таких напрямах, як-от: зміцнення професії соціального працівника у міжнародному масштабі; розвиток загальних стандартів і цілей із соціальної роботи; розвиток і актуалізація кодексу етики соціального працівника і стандартів професійної діяльності; захист прав людини і сприяння розробці соціальної політики; підтримка колег в країнах без професійної асоціації; розвиток освіти у галузі соціальної роботи у всьому світі; розробка стандартів для підвищення якості освіти в галузі соціальної роботи (Discussion document on Global Qualifying, 2004).

Системна робота профільних асоціацій і контролюючих органів дозволяє на постійній основі керувати процесом організації безперервної професійної освіти соціальних працівників та забезпечувати нерозривний зв'язок сучасної науки і професійної діяльності задля підтримання й покращення стандартів практики в усіх сферах професійної діяльності (Povidaichyk et al., 2021).

У Канаді надзвичайно важливого значення надається професійному розвитку соціальних працівників, але оскільки країна поділена на провінції, запроваджена децентралізована система управління цим процесом i вимоги до працівниківпрактиків відрізняються залежно від територіальної юрисдикції, в якій здійснюється професійна діяльність (Cheung, 2018).

В провінції Альберта необхідність і обов'язковість професійного розвитку соціальних працівників визначено провінційними законодавчими та нормативноправовими документами, зокрема Законом 
про медичні професії (Health Professions Act, 2003), Положенням про професії соціальних працівників (Social Workers Profession Regulation, 2012), а також Кодексом етики (Code of Ethics, 2005) та Стандартами практики соціальної роботи (Standards of Practice, 2019), офіційними документами Альбертійського коледжу соціальних працівників (Alberta College of Social Workers (ACSW). Основним змістом цих документів $\epsilon$ необхідність встановлення стандартів безперервної професійної компетентності соціальних працівників, які з одного боку є універсальними, а з іншого враховують специфіку різноманіття діяльності у професії та чітко відповідають етичним положенням та стандартам професійної діяльності, зокрема, соціальні працівники поважають право клієнта на отримання компетентних послуг; соціальні працівники аналізують природу соціальних потреб і проблем, заохочують інноваційні й ефективні стратегії і методи для задоволення як нових, так і існуючих потреб i, де це можливо, сприяють їх використанню у професійній діяльності; соціальні працівники зобов'язані підтримувати високий професіоналізм кваліфікації, постійно прагнути до підвищення своїх професійних знань і навичок, а також бути здатними застосовувати нові знання на практиці, які відповідають їхньому рівню професійної освіти, майстерності та компетентності, звертатися за консультацією та супервізії щодо своєї діяльності за необхідності.

Відповідальність за професійний розвиток у цій провінції Канади покладено на Альбертійський коледж соціальних працівників (Alberta College of Social Workers (ACSW), 2021), який одночасно $\epsilon$ і контролюючим органом і професійною асоціацією у сфері соціальної роботи в рамках територіальної юрисдикції. Нормативні зобов'язання коледжу закріплені у Законі про медичні професії (Health Professions Act, 2003), основні положення якого визначають мандатні цілі організації - служити суспільним інтересам і захищати їх; регулювати професію, зокрема встановлювати, підтримувати та дотримуватись етичним стандартам, стандартам реєстрації, безперервної компетентності; затверджувати освітні програми.
Альбертійський коледж соціальних працівників (Alberta College of Social Workers (ACSW), 2021) має свою організаційну структуру, яка складається з Ради альбертійського коледжу соціальних працівників (10 членів коледжу, 4 громадських активісти, призначених урядом, голова комітету соціальної роботи корінного населення), законодавчих комітетів (Реєстраційний комітет (Registration Committee), Комітет 3 питань компетенції (Competence Committee), Комітет з освіти професійної соціальної роботи (Professional Social Work Education Committee), Клінічний комітет (Clinical Committee), Дисциплінарний комітет (Discipline Committee) та Комітету соціальної роботи корінних народів (The Indigenous Social Work Committee advises Council).

Діяльність комітетів сприяє реалізації коледжем чотирьох основних функцій регуляторної, організаційно-практичної, контролюючої, адвокаційної. Суть регуляторної функції полягає у встановлені вимог і процедури щодо обов'язкової реєстрації соціальних працівників (Registered Social Worker (RSW), які здійснюють офіційну практику у провінціях Канади, а також щодо сертифікації освітніх програм, в рамках яких здійснюється професійна підготовка соціальних працівників. Організаційнопрактична функція передбачає підтримку членських заходів (конференцій, провінційних заходів), які пропагують кваліфіковану та етичну практику соціальної роботи і фактичне виконання повноважень професійної організації у сфері соціальної роботи, як наприклад, у інших провінціях Канади. Контролююча функція спрямована на перевірку відповідності професійної компетентності офіційно зареєстрованих соціальних працівників (RSW) на основі Програми безперервної компетентності (Continuing Competence Program (ССР), 2018). Адвокаційна функція полягає у захисті інтересів і прав населення від некомпетентності соціальних працівників та захисті прав соціальних працівників шляхом утвердження високого професійного іміджу і статусу професії, створення умов для безперервного професійного розвитку i навчання через відстоювання прогресивної соціальної політики, створення та участь у коаліціях з представниками уряду тощо. 
Реалізація коледжем цих функцій створює передумови для безперервного професійного розвитку соціальних працівників різних галузей практики, оскільки можливість працювати за цим фахом вимагає не тільки високоякісної першочергової бакалаврської/магістерської підготовки за сертифікованими програмами, але і офіційну реєстрацію та щорічний моніторинг професійної компетентності.

Відповідно до Закону про медичні професії (Health Professions Act, 2003) та Положенню про професії соціальних працівників (Social Workers Profession Regulation, 2012), соціальна робота належить до регульованого типу професій, що вимагає обов'язкової офіційної реєстрації практикуючих соціальних працівників у коледжі та присвоєння персоніфікованого облікового номеру. У провінції Альберта отримати статус практикуючого соціального працівника може особа, яка має диплом бакалавра/магістра у галузі соціальної роботи в рамках навчання на сертифікованих Канадською асоціацією соціальних працівників освітніх програмах. Також, стати офіційним соціальним працівником у провінції Альберта можливо і з міжнародним дипломом, однак необхідно отримати оцінку еквівалентності кваліфікації канадському ступеню бакалавра/магістра, отримати тимчасовий обліковий номер та протягом року скласти вступний іспит за результатами якого соціальний працівник може отримати свій персоніфікований номер фахівця практика у галузі соціальної роботи.

Усі зареєстровані і практикуючі соціальні працівники зобов'язані брати участь у Програмі безперервної компетентності (Continuing Competence Program (CСP), 2018), яка є офіційною, обов'язковою програмою сертифікації соціальних працівників (крім тих, хто має пенсійний клас свідоцтва про реєстрацію) у провінції Канади Альберта. Ї̈̈ основна мета - сприяння забезпеченню якості професійної діяльності у галузі соціальної роботи та соціального обслуговування, а також заохочення соціальних працівників-практиків постійно вдосконалювати свою професійну майстерність. Це один із способів виконання Коледжем свого мандату із захисту прав громадськості на отримання якісних послуг.
Програма безперервної компетентності (Continuing Competence Program (CCP), 2018), передбачає щорічну планомірну роботу з організації професійного розвитку за індивідуалізованим освітнім маршрутом протягом п'яти років. Кожен рік передбачає шести компоненту модель підвищення професійної компетентності за наступним алгоритмом: рефлексія та професійна самооцінка; розробка плану навчання; подання навчального плану на перевірку; здійснення підвищення кваліфікації; самооцінка результатів навчального плану; подання заповненої форми кредитів професійного розвитку (Professional Development Credits Form (PDCF).

Компонент «Рефлексія та професійна самооцінка» передбачає самоаналіз соціального працівника за чотирма складовими: організаційна практика, професійна практика, етична практика та особисті професійні інтереси. Інформація щодо цих складових заноситься у відповідну форму на основі якої розробляються цілі і завдання плану навчання на поточний рік. Після цього етапу розробляється навчальний план на рік, який заповнюється у вигляді таблиці, що містить інформацію про цільову компетентність, яку соціальний працівник має намір підтримувати або розвивати, конкретні цілі в рамках програми, які відображують професійний інтерес, а також співвідносяться із професійною самооцінкою, заплановані стратегії/активності, які планується реалізувати задля досягнення поставленої освітньої мети, виконані дії, які вдалося завершити, оцінку результатів діяльності протягом року.

Навчальний план має бути розроблений відповідно до спеціальної форми та з урахуванням кількості необхідних кредитів та навчальних годин, що відповідають вимогам до категорій різних видів освітньої діяльності в рамках програми безперервної компетентності.

У загальноканадській практиці в рамках програми безперервної компетентності розроблено 3 категорії кредитів для професійного розвитку (категорія А, В, С), якими у визначеному обсязі мають оволодіти соціальні працівники протягом року (Continuing Competence Program, 2018). Kaтегорія А - це сукупність видів освітньої діяльності, яка передбачає оволодіння но- 
вим матеріалом для здійснення основних професійних зобов'язань шляхом участі у сертифікованих освітніх курсах університетів, семінарах, навчальних програмах, конференціях тощо. Навчання здійснюється поза межами робочого часу соціального працівника і $€$ його додатковим навантаженням. Категорія В - це сукупність різних видів робіт, які пов'язані із виконанням своїх основних обов'язків в рамках робочого часу, але із урахуванням запланованих цілей визначених у навчальному плані. Категорія С - це діяльність, яка виконується для себе, через особистий професійний інтерес, і турботу про себе, але також із урахуванням запланованих цілей визначених у навчальному плані. Систематизація кредитів, що релевантна категоріям і формам зайнятості соціальних працівників представлена у таблиці 1.

Таблиця 1.

Категорії кредитів для професійного розвитку

\begin{tabular}{|c|c|c|c|c|c|}
\hline & Супервізія & Категорія A & Категорія B & Категорія C & $\begin{array}{l}\text { Загальна } \\
\text { кількість }\end{array}$ \\
\hline $\begin{array}{l}\text { Соціальні } \\
\text { працівники за } \\
\text { основним } \\
\text { місцем роботи }\end{array}$ & $\begin{array}{c}\text { не } \\
\text { передбачено }\end{array}$ & $\begin{array}{l}\text { мінімум } 10 \\
\text { кредитів }\end{array}$ & $\begin{array}{l}\text { немає } \\
\text { мінімуму }\end{array}$ & $\begin{array}{l}\text { немає } \\
\text { мінімуму }\end{array}$ & $\begin{array}{c}40 \\
\text { кредитів }\end{array}$ \\
\hline $\begin{array}{l}\text { Соціальні } \\
\text { працівники за } \\
\text { сумісництвом }\end{array}$ & $\begin{array}{c}\text { не } \\
\text { передбачено }\end{array}$ & $\begin{array}{l}\text { мінімум } 5 \\
\text { кредитів }\end{array}$ & $\begin{array}{c}\text { немає } \\
\text { мінімуму }\end{array}$ & $\begin{array}{c}\text { немає } \\
\text { мінімуму }\end{array}$ & $\begin{array}{c}20 \\
\text { кредитів }\end{array}$ \\
\hline $\begin{array}{l}\text { Неактивні } \\
\text { соціальні } \\
\text { працівника }\end{array}$ & $\begin{array}{c}\text { не } \\
\text { передбачено }\end{array}$ & $\begin{array}{c}\text { немає } \\
\text { мінімуму }\end{array}$ & $\begin{array}{l}\text { немає } \\
\text { мінімуму }\end{array}$ & $\begin{array}{c}\text { немає } \\
\text { мінімуму }\end{array}$ & $\begin{array}{c}10 \text { кредитів } \\
\text { (реко- } \\
\text { мендовано) }\end{array}$ \\
\hline $\begin{array}{l}\text { Клінічні } \\
\text { соціальні } \\
\text { працівники за } \\
\text { основним } \\
\text { місцем роботи }\end{array}$ & $\begin{array}{l}\text { мінімум } 10 \\
\text { кредитів }\end{array}$ & $\begin{array}{l}\text { мінімум } 20 \\
\text { кредитів }\end{array}$ & $\begin{array}{l}\text { немає } \\
\text { мінімуму }\end{array}$ & $\begin{array}{c}\text { немає } \\
\text { мінімуму }\end{array}$ & $\begin{array}{c}50 \\
\text { кредитів }\end{array}$ \\
\hline $\begin{array}{l}\text { Клінічні } \\
\text { соціальні } \\
\text { працівники за } \\
\text { сумісництвом }\end{array}$ & $\begin{array}{l}\text { мінімум } 5 \\
\text { кредитів }\end{array}$ & $\begin{array}{l}\text { мінімум } 10 \\
\text { кредитів }\end{array}$ & $\begin{array}{c}\text { немає } \\
\text { мінімуму }\end{array}$ & $\begin{array}{c}\text { немає } \\
\text { мінімуму }\end{array}$ & $\begin{array}{c}35 \\
\text { кредитів }\end{array}$ \\
\hline $\begin{array}{l}\text { Неактивні } \\
\text { клінічні } \\
\text { соціальні } \\
\text { працівники }\end{array}$ & 0 & $\begin{array}{l}\text { немає } \\
\text { мінімуму }\end{array}$ & $\begin{array}{c}\text { немає } \\
\text { мінімуму }\end{array}$ & $\begin{array}{c}\text { немає } \\
\text { мінімуму }\end{array}$ & $\begin{array}{c}20 \\
\text { кредитів }\end{array}$ \\
\hline
\end{tabular}

Після виконання навчального плану соціальний працівник заповнює форму з категоріями опанованих кредитів для професійного розвитку (PDCF) та підвантажує їі до свого особистого кабінету на перевірку. Усі звіти про самооцінку, плани навчальної діяльності та форми з категоріями опанованих кредитів за п'ятирічний період складаються у портфоліо і зберігаються в особистій справі соціального працівника, що відображує процес його безперервного професійного розвитку. Перевірка реального стану виконання Програми безперервної компетентності може здійснюватися комітетом $з$ питань компетенції Альбертійського коледжу соціальної роботи щорічно або після завершення програми.
Особливість програми безперервної компетентності полягає у тому, що вона $\epsilon$ універсальною і враховує всі відмінності багатьох сфер практики, які визнає Альбертійский коледж соціальної роботи (рис.1). Оскільки в іï основу покладено систему самооцінювання та рефлексію власної професійної діяльності на основі складання професійного портфоліо, яке відображує індивідуальну освітню траєкторію соціального працівника-практика з урахуванням сукупності його професійних інтересів (McCauley et al., 2018).

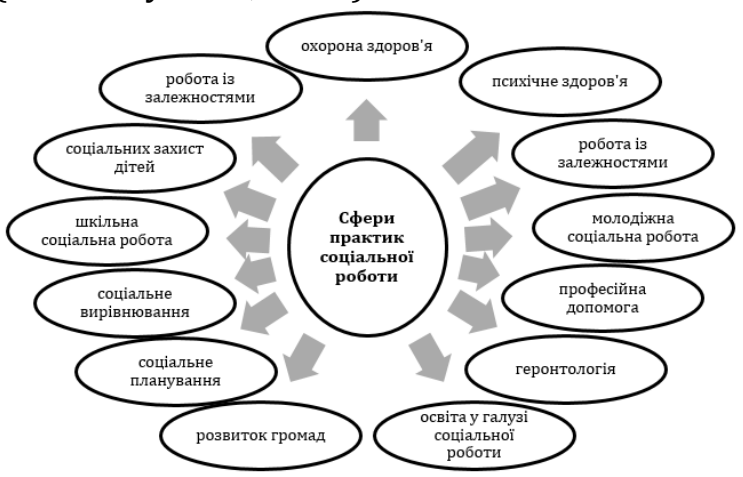

Рис.1. Сфери практик соціальної роботи у провінції Альберта

Враховуючи досвід організації безперервного професійного розвитку соціальних працівників у провінції Канади Альберта, необхідно заакцентувати увагу на тому, що постійне навчання паралельно із професійною практикою $є$ запорукою та гарантією якісної системи соціального обслуговування населення, дотримання прав людини, що сприяє розвитку соціальної справедливості, соціального добробуту населення й утверджує престиж професії соціального працівника. У цьому аспекті доречно запропонувати конструктивні ідеї альбертійської практики задля впровадження у національну систему соціальної роботи на загальнонаціональному та локальному рівнях.

Зауважимо, що в Україні системна робота з безперервного професійного розвитку соціальних працівників не здійснюється, тому доречним на загальнонаціональному рівні буде запровадження професійних асоціацій та спеціальних контролюючих органів у сфері соціальної роботи, які матимуть погоджений офіційний статус від міжнародних професійних організацій; розробка за затвердження етичного кодексу 
соціального працівника та стандартів його професійної діяльності; розробка впровадження загальнонаціональної стратегії та моделі системи безперервного розвитку для фахівців цієї галузі; удосконалення законодавчих і нормативно-правових документів у сфері соціальної освіти і соціальної практики. На локальному рівні необхідним $\epsilon$ розробка програм безперервної компетентності з урахуванням специфіки освітніх можливостей регіону; забезпечення взаємодії між різними типами закладів освіти і соціальної інфраструктури.

Висновки. Отже, безперервний професійний розвиток соціальних працівників в провінції Канади - це важливий елемент функціонування якісної професійної практики у цій галузі, який забезпечує нерозривний зв'язок сучасної науки і професійної діяльності і реалізується шляхом участі у програмі безперервної компетеності. Необхідність і обов'язковість професійного розвитку соціальних працівників у провінції Канади Альберта визначено Законом про медичні професії, Положенням про професії соціальних працівників, Кодексом етики та Стандартами практики соціальної роботи та обумовлено динамічною зміною соціального ландшафту. Відповідальність за професійний розвиток покладено на Аль- бертійський коледж соціальних працівників у межах повноважень якого реалізуються регуляторна, організаційнопрактична, контролююча, адвокаційна функції.

Такий системний підхід до організації безперервного професійного розвитку соціальних працівників забезпечує можливість реалізації права кожного громадянина Канади на якісне соціальне обслуговування, дотримання етичних і професійних стандартів, заохочення інноваційних й ефективних стратегій і методів професійної діяльності для задоволення як нових, так і існуючих потреб клієнтів, досягнення високого рівня соціальної справедливості і соціального розвитку та актуалізує вивчення, аналіз та узагальнення альбертійського досвіду задля створення української системи безперервного розвитку.

Стаття не вичерпує усіх аспектів досліджень з означеної проблематики. Перспективи подальших наукових пошуків вбачаємо у вивченні досвіду організації безперервного розвитку соціальних працівників інших провінцій Канади та їх узагальненні з метою виявлення прогресивних та конструктивних ідей загальноканадського досвіду та впровадження його в українську практику.

\section{ЛITEPAТУРА}

Alberta College of Social Workers (ACSW). (2018). Continuing Competence Program Member Handbook [Brochure]. https://acsw.in1touch.org/document/1949/CCP\%20Member\%20Handbook.pdf

Alberta College of Social Workers (ACSW). (2019). ACSW Standards of Practice. https://acsw.in1 touch.org/uploaded/web/website/DRAFT\%20ACSW\%20Standards\%20of\%20Prac tice\%20Bill\%2021\%20Implementation\%2002282019.pdf

Alberta College of Social Workers (ACSW, November). (2021). About ACSW. https://www.acsw.ab.ca/site/about?nav=sidebar

Alberta Government. (2003). Health Professions Act. https://www.qp.alberta.ca/documents/Acts/h07.pdf

Alberta Government. (2012). Social Workers Profession Regulation. https://open.alberta.ca/dataset/1c11bd09-ff64-42e7-bc5b-b07c19e83c02

Canadian Association of Social Worker. (2005). CASW Code of Ethics. https://www.bcasw.org/wpcontent/uploads/2011/09/CASW Code-of-Ethics e.pdf

Canadian Association of Social Workers (CASE). (2021, November). Professional Development. https://www.casw-acts.ca/en/continuing-education/professional-development

Cheung, J. C. S. (2018). A social worker with two watches: Synchronizing the left and right ideologies. International Social Work, 61(2), 234-246. https://doi.org/10.1177/0020872815620259

International Association of Schools of Social Work; International Federation of Social Work. (2004). Discussion document on Global Qualifying Standards in Social Work. http://www.iasswaiets.org/global-standards-for-social-work-education-andtraining/

Ireland's multi-profession health regulator (CORU). (2021, November). Social Workers Registration Board. https://coru.ie/health-and-social-care-professionals/education/continuing-professionaldevelopment/cpd-for-social-workers/

Local Government Association in England. (2021, November). Standard 6 - Continuing professional development (CPD). https://local.gov.uk/standard-6-continuing-professional-development-cpd 
McCauley, K. \& Matheson, D. (2018). Social Work Practice with Canada's Indigenous People: Teaching a Difficult History. Practice, 30(4), 293-303. https://doi.org/10.1080/09503153.2018.1483493

Nuttman-Shwartz, O. (2016). Rethinking professional identity in a globalized world. Clinical Social Work Journal, 45(1), 1-9. https://doi.org/10.1007/s10615-016-0588-Z

Povidaichyk, O., Pedorenko, V., Popova, A., Turgenieva, A., Rybinska, Y., \& Demchenko, I.. Research Paradigm as a Value Guideline for Professional Training of Future Social Workers. Revista Romaneasca Pentru Educatie Multidimensionala, 13(3). (2021). $\quad$ P. $530 \quad$ - 547. https://doi.org/10.18662/rrem/13.3/465.

Анастасія Попова, кандидат педагогічних наук, заступник декана з наукової та міжнародної діяльності Факультету дошкільної, спеціальної та соціальної освіти Бердянського державного педагогічного університету, старший викладач кафедри соціальної роботи та інклюзивної освіти Бердянського державного педагогічного університету, голова Ради молодих учених Бердянського державного педагогічного університету.

Anastasia Popova, PhD in Pedagogy, Deputy Dean for Scientific and International Activities of the Faculty of Preschool, Special and Social Education, Senior Lecturer of Department of Social Work and Inclusive Education (Berdiansk State Pedagogical University), the Head of the Council of Young Scientists of Berdiansk State Pedagogical University.

E-mail: kovaleva.anastasia.45@gmail.com ORCID ID 0000-0001-5176-0059 